\begin{tabular}{|c|c|c|c|c|c|}
\hline $\begin{array}{l}\text { Layers of c.c.p. : A } \\
\text { O layers of c.c.p. : }\end{array}$ & $\mathrm{C}$ & $\mathrm{B}$ & A & $\mathrm{C}$ & \\
\hline $\begin{array}{l}\text { Anion layers with : A } \\
\text { simple cubic pack. }\end{array}$ & $\mathrm{C}$ & B & A & $\mathrm{C}$ & (6) \\
\hline $\begin{array}{l}\text { Layers of body- } \\
\text { centered sites }\end{array}$ & B & A & $\mathrm{C}$ & B & \\
\hline Notation & & , & $\ldots$ & $S(f)$ & \\
\hline
\end{tabular}

層の增間距離との比が $\sqrt{2} / \sqrt{3}$ (c.c.p. では $\sqrt{2} / 2 \sqrt{3}$ ) とな る。 $\mathrm{CsCl}$ 型から誘導できる構造を表 7 に示した。 $\mathrm{CsCl}$ 型の陽イ オンを一層扣きに抜くと $\mathrm{CaF}_{2}$ 型（表 3 参照）となるが，陽イオ ンの配位が上下それぞれ 2 層におよぶため, c. c. p. の場合のよう

\author{
な層状構造は形成されない。 \\ 表 2〜7 に示したよらに, 無機化合物の結晶の多くは, 最密充 \\ テンまたはそれに関連した構造として積層表示できる ${ }^{12)}$ ここに \\ 報告した表示法は, 従来のと比較して, これらの多様な構造を簡 \\ 潔に表現し，各構造の関連性を示すのにも適している。
}

12） R. W. G. Wyckoff, “Crystal Structures”（胿注 10）の Vol. I 〜正に記載されている約 4000 の結晶（水和物を除 く）の5ち，6割まではここに積層表示した構造の同形， または近い構造をとり，その他の結晶についても，これら に関連した構造が少なくない.

\title{
A New Notation System of Close-packed and Its Related Structures
}

\author{
Masaki Miyahara and Yoshio Otsubo \\ Department of Inorganic Chemistry, Waseda University ; \\ Nishiohkubo, Shinjuku-ku, Tokyo 160 Japan
}

A new simple notation.describing close-packed structures was given. The layer sequence of close-packed anions was represented by the symbols of polytypism, and the arrangement of cations in the tetrahedral and octahedral voids was indicated briefly by the fractions of the voids occupied. A rhenium trioxide and a cristobalite structures were expressed in terms of defect of anions from close-packing. The arrangement of cesium chloride was also represented by a stackingof ionic layers. The structures of about a hundred inorganic compounds were described (Table $2 \sim 7$ ), and the correlation of these structures was discussed.

(日本化学会誌, 1974,（1）, p. 191～193）

\section{水銀法アルカリ塩水電解槽における金属電極短絡検出法 ${ }^{122}$}

\author{
(1973 年 6 月 12 日受理)
}

北野 孝 久*

\section{1 緒言}

水銀法アルカリ塩水電解槽の陽極として, 従来は黒鉛が使用さ れてきたが, 最近, 金属電極が開発され, 技術革新が目覚まし (3)4)。この金属電極の使用可能な電流密度は, 黒鉛にくらべ高 いので, 経済的に極間距離を可能ながり短縮して, 電力原単位 の低減を計る必要がある。したがって水銀法電解槽の操業技術が 一変してきた。その重要な要因は,

1）黑鉛電極は電解時間の経過とともに消耗して, 陰極水銀面 との距離が均一化する傾向をむっている。それに反して，金属電 極は, $1 / 10 \mu$ (ミクロン) 単位の被覆白金族金属が消耗する程度 で, 形状はまったく変化しない。

1）この報文を “水銀法電解槽の研究（第 2 報）”とする.

2）前報(第 1 報)，北野孝久，岡崎利昌，上田哲夫，日化， 1973, 1110 .

* 愛知県稲沢市奥田町山ヶ田 5091 の 9

3）特公昭 35-10762, Henri Bernard Beer.

4）特公昭 48-3954, Henri Bernard Beer.
2）したがって金属電極を組立てるさい，陽極面は黒鉛にくら べ，さらに水平にする必要がある。

3）一方, 陰極水銀㬝の厚さは, 通電当初 $2 \sim 3 \mathrm{~mm}$ になって いるが，電解開始ととすに底部無流動層が增加して，5６ $\mathrm{mm}$ になる5゙。さらにブスバーによる磁力の影響が加わって, 部分的 に急激に厚くなり，その部分の金属電極は一瞬にして短絡焼失す る。などである。

したがって金属電極短絡焼失を防止する目的で，自動極間調整 法の研究, および短絡検出法の研究が行なわれている。本報告で は，後者の短絡検出法について述べる。また本研究により，陰極 水銀波の厚さを知ることが可能になった。

\section{2 実 験 方 法}

大容量電解槽においては，部分的に極間距離が短樎 してくる

5）電解の経過とともに，水銀が鉄，シリカ，黒鉛粉，塩水中 不純物 $(\mathrm{Ca}, \mathrm{Mg})$ ，白金族金属類などに污染されて, ア ルガムバターになり，陰極底盤に付着して無流趿周を形成 する。 


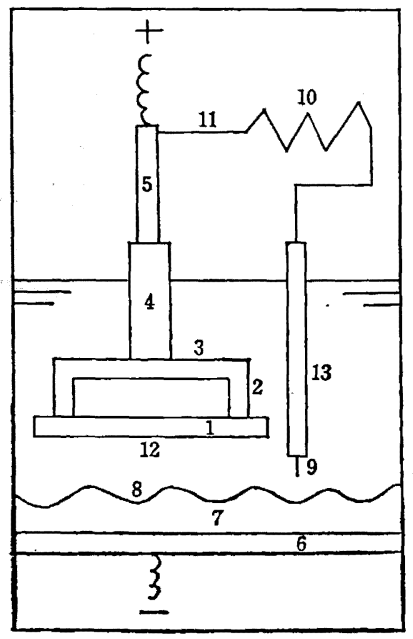

Fig. 1 Experimental apparatus

1: Working surface, $2:$ Ti rib, $3:$ Ti bar, 4 : Protector, 5 : Anode stem, 6 : Steel bed, 7 : Amalgam layer, 8 : Ripple of amalgam flow, $9:$ Pt probe, $10:$ Resistance, $11:$ Circuit, $12: \mathrm{Cl}_{2}$ gas diffusion layer, $13:$ Insulator

そ，その部分電流が全体平均電流より上昇し，部分端子電圧は低 下してくる。この場合，他の場所では反対に電流が低下し，端子 電圧は上昇してくる。この電流変化，あるいは電王変化ともに短 絡事前予知警報数值 $(\mathrm{d} I / \mathrm{d} t$, あるいは $\mathrm{d} E / \mathrm{d} t)$ として使用するこ とが可能である゙)。

また，従来より陽極面に絶縁された白金突出部をつくり，これ と陰極とを外部抵抗を通して短絡し，そのさい抵抗を通して流れ る電流の変化量を測定し，金属電極短絡焼失を事前に認知する方 法が研究されている(以下この方法をソルベー法と呼ぶ）。

著者は、ソルベー法と反対に白金線突出部を陽極としてバイパ ス電解電流を流して，短絡を事前に予知する方法が現場的に見て 使用容易であると考察した。本研究では，この方法で実験を行な らことにした8)。

実験装置を図1に示す。 $1 \mathrm{KA} ， 40 \mathrm{KA} ， 80 \mathrm{KA} ， 200 \mathrm{KA}$ など の実用的な各容量の水銀法電解槽に挿入して実験を行なった。

\section{3 実験結果および考察}

実験結果は実測値の一例を図 2 に示す。 $1 \mathrm{KA}, 40 \mathrm{KA}, 80 \mathrm{KA}$, $200 \mathrm{KA}$ なとの各容量電解槽についての測定結果も同じであっ た9)。

1）実用電解槽の極間距離（水銀波を含む）は

6) 陽極降下速度を一定化して，降下時間当りの電流变化 $(\mathrm{d} I / \mathrm{d} t)$ ，また電圧変化 $(\mathrm{d} E / \mathrm{d} t)$ として，沶の抹のの基準以 上飞なると短絡警報を出すように設計する。

7）実用新案公昭 48-5142, Robert Schoberle（ソルベー).

8）测 定方法 白金突出部 測定計器
著者の方法
陽 極 ボルトメーター
ソルベー法
陰極洂ルトメーター

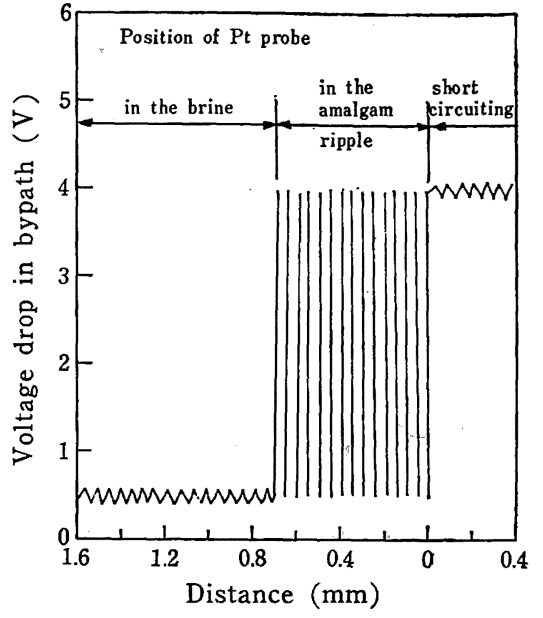

Fig. 2 An example of voltage vs distance curve Obtained at $60 \mathrm{KA}\left(100 \mathrm{~A} / \mathrm{dm}^{2}\right)$

\section{平常管理の電解槽 $\quad 3.0 \mathrm{~mm}$ \\ よく管理された電解槽 $\quad 1.5 \mathrm{~mm}^{12)}$}

であるが，本実験では上記範囲の極間距離が変化しても，ハイパ ス電流の変化が小さい。

2）水銀波中では，接触電流は上下に大きく振幅する ${ }^{10)} 。$

3）短絡すれば，短絡電流は大きく，ほとんど一定である。

4）水銀波の厚さは，0.5 1.0 mm である ${ }^{11) 。 ~}$

5）金属電極は，水銀波に接触した場合，小容量電解槽 $(40$

$\mathrm{KA})$ のときは焼失しなくて，大容量電解槽のときは焼失した。

6）白金線を陽極としてバイパス電流を流すことにより，金属 電極の短絡を事前に予知することができた。

7）端子電圧を減少させる極限極間距離は，陽極塩素ガス分散 層2) が陰極水銀波に接触しない点である(12)。したがって塩素がス 分散層，および水銀波を極力薄くする必要がある。

8）水銀波の厚さは，1）陰極底盤の摩擦係数，口）陰極底盤 の傾斜，八）水銀流量，＜wide>）電流密度，一）塩水流量，卜）水銀 純度，などに影響され，今後の工学的解析が期待される。

本研究に協力された岡崎利昌，上田哲夫，湊辉男の三氏に感 謝します。

9）各容量電解槽の最大電流密度; $1 \mathrm{KA}\left(500 \mathrm{~A} / \mathrm{dm}^{2}\right), 40 \mathrm{KA}$ $\left(75 \mathrm{~A} / \mathrm{dm}^{2}\right), 80 \mathrm{KA}\left(130 \mathrm{~A} / \mathrm{dm}^{2}\right), 200 \mathrm{KA}\left(95 \mathrm{~A} / \mathrm{dm}^{2}\right)$ 使用金属電極は，白金族金属酸化物でなく白金族金属治金 皮膜である（X楾回折により確認している）

10）水銀波中

11）白金楾が水銀波に接触すると電流が大きく振幅する，その 䈏团が水銀波の厚さである。

12）極限極間距離計算例

第 1 報 陽極塩素ガス分散㬝の厚さ $0.692 \mathrm{~mm}$

第 2 報 陰極水銀波の厚さ

$0.500 \mathrm{~mm}$

極限極間距離
計 $1.192 \mathrm{~mm}<1.5 \mathrm{~mm}$ 実用栖間距離 


\title{
A Detection Method of the Short Circuit of Electrodes During the Operation of the Mercury Alkali-chlorine Cell ${ }^{+}$ \\ Takahisa Kitano \\ Yamagada, Okuda, Inazawa City, Aichi 492 Japan
}

The detection of a short circuit of electrodes in the mercury cell was successfully carried out by passing by-pass current to the $\mathrm{Pt}$ anode probe.

The amalgam ripple on the cathode was found to be unexpectedly high (the thickness of the amalgam ripple: $0.5 \sim 1.0 \mathrm{~mm}$ ), for which fact the technological analysis would be expected.

$\dagger$ The Study of the Mercury Cell. II.

（日本化学会誌, 1974, (1), p. 193 195)

\section{遷移金属塩の存在下における臭化ブチルマグネシウムと 塩化アリルとの反応における配位子の効果 ${ }^{122}$}

\author{
(1973 年 7 月 12 日受 理)
}

大部芳広・土井清人・松田勗*

\section{1 緒言}

前報に括いて，触媒量の遷移金属塩 $(\mathrm{Ni}, \mathrm{Co}, \mathrm{Fe}$ 抢よび $\mathrm{Cu})$ の存在下に拈ける臭化ブチルマグネシウムと塩化アリルとの反応 に持いては， Ni，Co 塩を用いると塩化アリルが還元されたプロ ピレンと臭化ブチルマグネシウムのブチル基から水素の脱離した ブテンが主として生成するが3)， ハロங゙ン化クロチルとの反応で は，ハロゲン化クロチル同志のカップリング生成物 $\left(C_{8}-\right.$ ジェン 混合物）が主生成物となることを報告した2)。このように 2 種の アリル型ハロゲン化合物の間で生成物の種類に大きい差異がある が， $\mathrm{Ni}, \mathrm{Co}$ 塩を用いる場合には, いずれも $\pi$-アリル金属中間体 を含む反応径路で説明され, 臭化ブチルマグネシウムのアルキ ル基における $\beta$-水素の挙動が生成物の種類と密接に関連してい ることがわかっだ2。最近, 能田ら゙)はニッケルホスフィン錯体 の存在下，ハロゲン化ビニルおよびハロベンゼンが Grignard 試 薬と反応して，好収率でクロスカップリング生成物を与えること を報告している。本報告では上記のアリル型ハロゲン化合物と臭 化ブチルマグネシウムとの遷移金属塩存在下の反応に括ける配位 子の効果について調べた。

1）この報文を“遷移金属塩を触媒とするGrignard 試薬の反 応 (第 5 報)” とする.

2）前報(第 4 報)，Y.Ohbe, T.Matsuda，Tetrahedron，29， 2989 (1973).

* 九州大学工学部合成化学教室, 812 福岡市東区箱崎

3) Y.Ohbe, T.Matsuda, Bull. Chem. Soc. Jap., 45, 2947 (1972).

4) K. Tamao, K.Sumitani, M.Kumada, J. Amer. Chem, Soc., 94, 4374(1972).
2 実験

\section{1 反忘操作}

窒素雾囲気下で調製し，過剩のマグネシウムを汇別して得た臭 化ブチルマグネシウムのエーテル溶液 $(0.1 \mathrm{~mol})$ を $200 \mathrm{ml}$ の三 つロフラスコにとり, 所定量の配位金属塩を加えて, ガスの発 生が止まるまで加熱還流し (A反応), つついて木冷下, 塩化ア リル(0.1 mol) のエーテル溶液を加えてふたたび加熱還流した（B 反応)。A，B両反応の発生ガス量を測り，反応混合物を $10 \%$ 希 硫酸を加えて加水分解し，常法により処理した。生成物の分析は いずれあガスクロマトグラフによって行なった。A，B両反応で 発生したガス状生成物は, Benzyl ether $40 \%, 3 \mathrm{~mm} \times 6 \mathrm{~m}$ カラ ムを用いてプロピレン，ブタン，ブテンを定量し，加水分解して 得られた液状生成物は乾燥したエーテル溶液に内部基準としてシ クロヘキセンを加え, Golay カラム HB 2000，45 m を用いて 1,5-ヘキサジェン，1-ヘプテン，オクタンを定量した。な和 A反 応に拈いて発生したガスは表 1 に示した実験のいずれにおいても $130 \mathrm{ml}$ 以下で, ブタン $2 \sim 4 \%$, ブテン $2 \sim 3 \%$ (および多量の 窒素）を含んでいた。

\section{3 結果亡考察}

Kochi ら ${ }^{\text {5) }}$ は臭化アルキルマグネシウムと塩化パラジウムとの 反応に批いて，トリフェニルホスフィンを加えると Grignard 試 薬のアルキル基同志のカップリング生成物が増加することを認め ている。これはよく知られているよらに尕，〔1〕のような卧位子

5) M. Tamura, J. K, Kochi, Bull. Chem. Soc. Jap., 44, 3063(1971), 